\title{
Resistance Pattern of Antibiotics in Patient Underwent Open Heart Surgery with Nosocomial Infection in North of Iran
}

\author{
Alireza Davoudi ${ }^{1}$, Narges Najafi ${ }^{1}$, Shahriar Alian ${ }^{1}$, Atefe Tayebi ${ }^{1}$, Fatemeh Ahangarkani ${ }^{1}$, Samaneh Rouhi ${ }^{2,3}$ \& \\ Amirhosein Heydari ${ }^{1}$ \\ ${ }^{1}$ Antimicrobial Resistance Research Center, Department of Infectious Diseases, Mazandaran University of \\ Medical Sciences, Sari, Iran \\ ${ }^{2}$ Student Research Committee, Kurdistan University of Medical Sciences, Sanandaj, Iran \\ ${ }^{3}$ Cellular \& Molecular Research Center and Department of Microbiology, Kurdistan University of Medical \\ Sciences, Sanandaj, Iran \\ Correspondence: Fatemeh Ahangarkani, Antimicrobial Resistance Research Center, Department of Infectious \\ Diseases, Mazandaran University of medical sciences, Sari, Iran. Tel: 98-911-854-5931. E-mail: \\ fkani63@gmail.com
}

Received: June 12, 2015 Accepted: July 20, 2015 Online Published: August 5, 2015

doi:10.5539/gjhs.v8n2p288 URL: http://dx.doi.org/10.5539/gjhs.v8n2p288

\begin{abstract}
Background: Patients who undergo cardiac surgery appear to be at increased risk for the development of Nosocomial infections (NIs). The development of antibiotic-resistant infections has been associated with significantly greater hospital mortality rates compared to similar infections caused by antibiotic-sensitive pathogens.
\end{abstract}

Objectives: The purpose of this study is survey of Nis and antibiotic resistance patterns of causative bacteria among patients who underwent open heart surgery in the north of Iran during a 2-year period between September 2012 and September 2014.

Methods: In this cross-sectional study we evaluated 187 patients that underwent open heart surgery with NIs. Demographic feature, clinical characteristics and risk factors of each infection were recorded. The antibiotic susceptibility test was performed using the Minimum inhibitory concentration (MIC) method according to the standard protocol of Clinical \& Laboratory Standards Institute (CLSI). Detection of Extended-spectrum beta-lactamase (ESBL) producing bacteria was performed by the double-disk synergy (DDS) test; also Methicillin-resistant Staphylococcus (MRSA) strains were identified by MRSA Screen Agar. The collected data were analyzed using the SPSS software (ver. 16) and, descriptive statistics were used.

Results: Out Of total of 2253 hospitalized patients who underwent open heart surgery, 187(5.05\%) patients had NIs. $51.9 \%$ of the patients were female. The rates of surgical site infection (SSI), respiratory tract infection, endocarditis, Urinary tract infection (UTI), blood Infection and mediastinitis were 27.80, 25.66\%, 17.64, 17.11\% $8.55 \%$ and $3.20 \%$ respectively. E.coli and S.aureus were the most causative agents of NIs. The rate of ESBL-producing bacteria was $14.28-71.42 \%$ among enterobacteriaceae and the rate of MRSA was $54.2 \%$ among S.aureus strains. All isolated Acinetobacter.spp were Multi-drug resistance (MDR).

Conclusions: We showed that the rate of NIs among these high-risk patients was in the average level. But the emergence of MRSA and ESBL bacteria is increasing in our region.

Keywords: nosocomial infection, antibiotic resistance, open heart surgery, ESBL, MRSA

\section{Introduction}

Nosocomial infections (NIs) pose a serious threat to patients, especially in the high-risk wards (Ding et al., 2009). Globally, $8.7 \%$ of the hospitalized patients are affected with NIs (Behzadnia et al., 2014). NIs after open heart surgery represent serious complications corresponding with significant morbidity, mortality, increased need for antimicrobial therapy and economic burden (Lola et al., 2011). NIs have been reported to occur in 5-21\% of cardiac surgery patients and in these patients, infections are serious and often life-threatening complications (Kollef et al., 1997; Michalopoulos et al., 2006). Patients who undergo cardiac surgery appear to be at increased 
risk for the development of NIs due to the presence of multiple surgical wounds, frequent postoperative utilization of invasive devices, and the common use of antibiotics in the perioperative period. Additionally, current administration practices of antibiotics may help to explain the emergence of NIs due to antibiotic resistant pathogens in this and other groups of critically ill patients. The development of such antibiotic-resistant infections has been associated with significantly greater hospital mortality rates compared to similar infections caused by antibiotic sensitive pathogens. Common problem in the treatment of NIs is the increase of antibiotic-resistant organisms (Kollef et al., 1995; Goldmann et al., 1996; Rahmati et al., 2014). Prevention of NIs remains of the uttermost importance. Identifying NIs risk factors and antibiotic resistance pattern of causative agents which vary between populations, is important in preventing infection in any patient who underwent open heart surgery. To the best of our knowledge this study is the first surveillance on patients that underwent open heart surgery with NIs in the north of Iran. The purpose of this study is survey of NIs and antibiotic resistance patterns of causative bacteria among patients who underwent open heart surgery in the Fatemeh Zahra teaching hospital to help the physicians choose better antibiotics in the start of empiric therapy.

\section{Material and Methods}

\subsection{Study Population and Design}

This is a cross-sectional study. This study was approved by the Ethics Committee of Mazandaran University of Medical Sciences (Code No: 9135, Date: July 11, 2012). All the patients with NIs who were admitted to Fatemeh Zahra teaching hospital (a governmental heart surgery center in Mazandaran province, northern Iran) in the period between September 2012 and September 2014 were studied. All these patients underwent open heart surgery. The census method was used for sampling. NIs were defined based on the National Directory of Nosocomial Infections Surveillance System (Masoumi, 2007). We gathered information that included demographic and clinical characteristics, risk factors, and medical history, and main diagnosis, types of NIs and clinical samples of the patients that had NIs.

\subsection{Clinical Sample Collection and Identification of Bacteria}

Samples included deep tissue infected through the wounds of surgical sites, sputum, tracheal secretions, wound debridement of infected tissue, drainage of mediastinum infected tissues, urine and blood. Sampling was done by the head nurse and the samples were immediately transported in a transport medium to the hospital's microbiology laboratory (To prevent the loss of some of the microorganisms present in the samples that take some time to culture and stain in the laboratory; we used Stuart transport medium). Identification of the organisms causing infection was performed according to the standard microbiological procedures (Koneman et al., 1997; Collee et al., 1996).

\subsection{Antimicrobial Susceptibility Test}

Susceptibility of the clinical isolates to routinely used antibiotics was determined by the standard broth dilution (micro dilution broth) technique. MIC is defined as the lowest concentration of an antibiotic that inhibits the visible growth of bacteria after overnight culture. The bacterial suspension equivalent to 0.5 McFarland standards was prepared provided in Müller-Hinton Broth (MHB) (Merck, Germany). The final standard concentration of the bacteria was increased to $5 \times 10^{5} \mathrm{CFU} / \mathrm{ml}$. Serial concentrations of antibiotics were prepared from $512 \mu \mathrm{gr} / \mathrm{ml}$ to $1 \mu \mathrm{gr} / \mathrm{ml}$. MIC was determined according to the recommendations of the standard protocol of CLSI(CLSI, 2010). The antibiotics that were used were Ceftriaxone, Ciprofloxacin, Gentamicin, Clindamycin, Oxacillin, Penicillin, Cotrimoxazole, Ampicillin, Vancomycin, Amikacin, Ceftazidime, Imipenem, Norfloxacin, Cefazolin and Novobiocin. The antibiotics were purchased from Sigma chemical company.

\subsubsection{Detection of Extended-Spectrum Beta-Lactamase (ESBL) Producing Enterobacteriaceae}

ESBL-producing enterobacteriaceae was detected using the double-disk synergy (DDS) test (Ramazanzadeh, 2010, Jarlier et al., 1988). ESBL presence was assayed using the following antibiotic disks (MAST, UK): cefotaxime $(30 \mu \mathrm{g})$, cefotaxime/clavulanic acid $(30 / 10 \mu \mathrm{g})$, ceftazidime $(30 \mu \mathrm{g})$, and ceftazidime/clavulanic acid $(30 / 10 \mu \mathrm{g})$. Escherichia coli ATCC 25922 strains served as positive control.

\subsubsection{Detection of Methicillin-Resistant Staphylococcus (MRSA) Strains}

For detection of methicillin-resistant Staphylococcus strains, Oxacillin Screen Agar (originally named MRSA Screen Agar) was used. Staphylococcus strains were cultured on Muller Hinton agar containing 4\% $\mathrm{NaCl}$ and 6 $\mathrm{mg} / \mathrm{L}$ oxacillin and were incubated for 24 hours.

\subsection{Statistical Analysis}

The collected data were analyzed using SPSS software (ver. 16). Descriptive statistics were used. 


\section{Results}

Out of total of 2253 hospitalized patients with open heart surgery in the north of Iran during the 2-year period between September 2012 and September 2014, 187(5.05\%) had NIs from which 90(48\%) were female and $97(51.9 \%)$ were male. The average age was $63.45 \pm 14.14$ years old. The average duration of hospitalization was $7.32 \pm 3.42$ days.

The prevalence of surgical site infection (SSI), respiratory tract infection, endocarditis, urinary tract infection (UTI), blood Infection and mediastinitis were $27.80 \%, 25.66 \%, 17.64 \%, 17.11 \%, 8.55 \%$ and $3.20 \%$ respectively.

The demographic feature, risk factors and clinical characteristics of every infection have been demonstrated in table 1and 2; the incidence causative agent of NIs are portrayed in table 3 and antibiotic resistance pattern of the bacteria that cause NIs are given in tables 4 and 5 .

The prevalence of ESBL bacteria for P. aeruginosa, Acinetobacter.spp, E.coli, Enterobacter .spp and Klebsiella .spp were 4(33.3\%), 5(71.42\%), 8(27.58\%), 2(25\%) and $1(14.28 \%)$ respectively. The rates of MRSA Staphylococcus strains for S.aureus and S. epidermidis were 26(54.2\%) and 2(100\%).

Table 1. Demographic feature and risk factors of infection

\begin{tabular}{|c|c|c|c|c|c|c|c|c|}
\hline & & $\begin{array}{l}\text { Respiratory } \\
\text { tract } \\
\text { Infection } \\
\text { No. (\%) }\end{array}$ & $\begin{array}{l}\text { SSI } \\
\text { No. (\%) }\end{array}$ & $\begin{array}{l}\text { UTI } \\
\text { No. (\%) }\end{array}$ & $\begin{array}{l}\text { Blood } \\
\text { Infection } \\
\text { No. (\%) }\end{array}$ & $\begin{array}{l}\text { Mediastinitis } \\
\text { No. (\%) }\end{array}$ & $\begin{array}{l}\text { Endocarditis } \\
\text { No. (\%) }\end{array}$ & $\begin{array}{l}\text { Total } \\
\text { No. (\%) }\end{array}$ \\
\hline \multirow[t]{2}{*}{ Gender } & Female & $22(45.5)$ & $22(42.3)$ & $22(68.78)$ & $8(50)$ & $1(16.7)$ & $16(48.5)$ & $90(48)$. \\
\hline & Male & $26(54.5)$ & $30(57.7)$ & $10(31.25)$ & $8(50)$ & $5(83.3)$ & $17(51.5)$ & $97(51.9)$ \\
\hline Age & Year & $63.75 \pm 13.81$ & $65 \pm 9.2$ & $68 \pm 12.68$ & $67.7 \pm 16.25$ & $57 \pm 4.18$ & $55.96 \pm 18.12$ & $63.45 \pm 14.14$ \\
\hline $\begin{array}{l}\text { Average } \\
\text { duration } \\
\text { hospitalization }\end{array}$ & Day & $7.1 \pm 2.2$ & $6.2 \pm 1.7$ & $7.1 \pm 5.23$ & $6.93 \pm 1.65$ & $8.5 \pm 3.67$ & $8.15 \pm 6.2$ & $7.32 \pm 3.42$ \\
\hline \multirow[t]{13}{*}{ Risk factor } & Diabetes & $15(34.1)$ & $26(50)$ & $8(25)$ & $9(56.3)$ & $6(100)$ & $11(33.3)$ & $83(44.4)$ \\
\hline & HTN & $24(54.5)$ & $29(55.8)$ & $19(59.37)$ & $10(62.5)$ & $4(66.7)$ & $8(24.2)$ & $94(50.3)$ \\
\hline & $\begin{array}{l}\text { Cardiovascular } \\
\text { disease }\end{array}$ & $21(31.7)$ & $22(42.3)$ & $11(34.37)$ & $8(50)$ & $4(66.7)$ & $5(15.2)$ & $71(38)$ \\
\hline & Urine catheter & $13(27.8)$ & $13(25)$ & $23(71.87)$ & $7(43.8)$ & $6(100)$ & $9(27.3)$ & $101(54)$ \\
\hline & $\begin{array}{l}\text { Central venous } \\
\text { device }\end{array}$ & 0 & 0 & 0 & 0 & $3(50)$ & $2(6.06)$ & $\mathbf{5}(2.67)$ \\
\hline & $\begin{array}{l}\text { Mechanical } \\
\text { intubation }\end{array}$ & $41(93.2)$ & $12(23.1)$ & $13(40.62)$ & $5(31.3)$ & $6(100)$ & $8(24.2)$ & $85(45.5)$ \\
\hline & Steroid therapy & $1(2.3)$ & 0 & $3(9.37)$ & 0 & 0 & $4(12.1)$ & $8(4.3)$ \\
\hline & Lung diseases & $5(11.4)$ & $11(21.2)$ & $6(18.75)$ & 0 & 0 & $2(6.1)$ & $24(12.7)$ \\
\hline & Liver Cirrhosis & $2(4.5)$ & 0 & $2(6.25)$ & 0 & 0 & 0 & $4(2.1)$ \\
\hline & Renal failure & $6(13.6)$ & $1(1.9)$ & $5(15.62)$ & $3(18.8)$ & 0 & $2(6.1)$ & $17(9.1)$ \\
\hline & Malignancy & 0 & 0 & 0 & 0 & 0 & 0 & 0 \\
\hline & Chemotherapy & 0 & 0 & 0 & 0 & 0 & 0 & 0 \\
\hline & Transplantation & 0 & 0 & $3(1.6)$ & 0 & 0 & 0 & $3(1.6)$ \\
\hline
\end{tabular}


Table 2. Clinical characteristics of infection

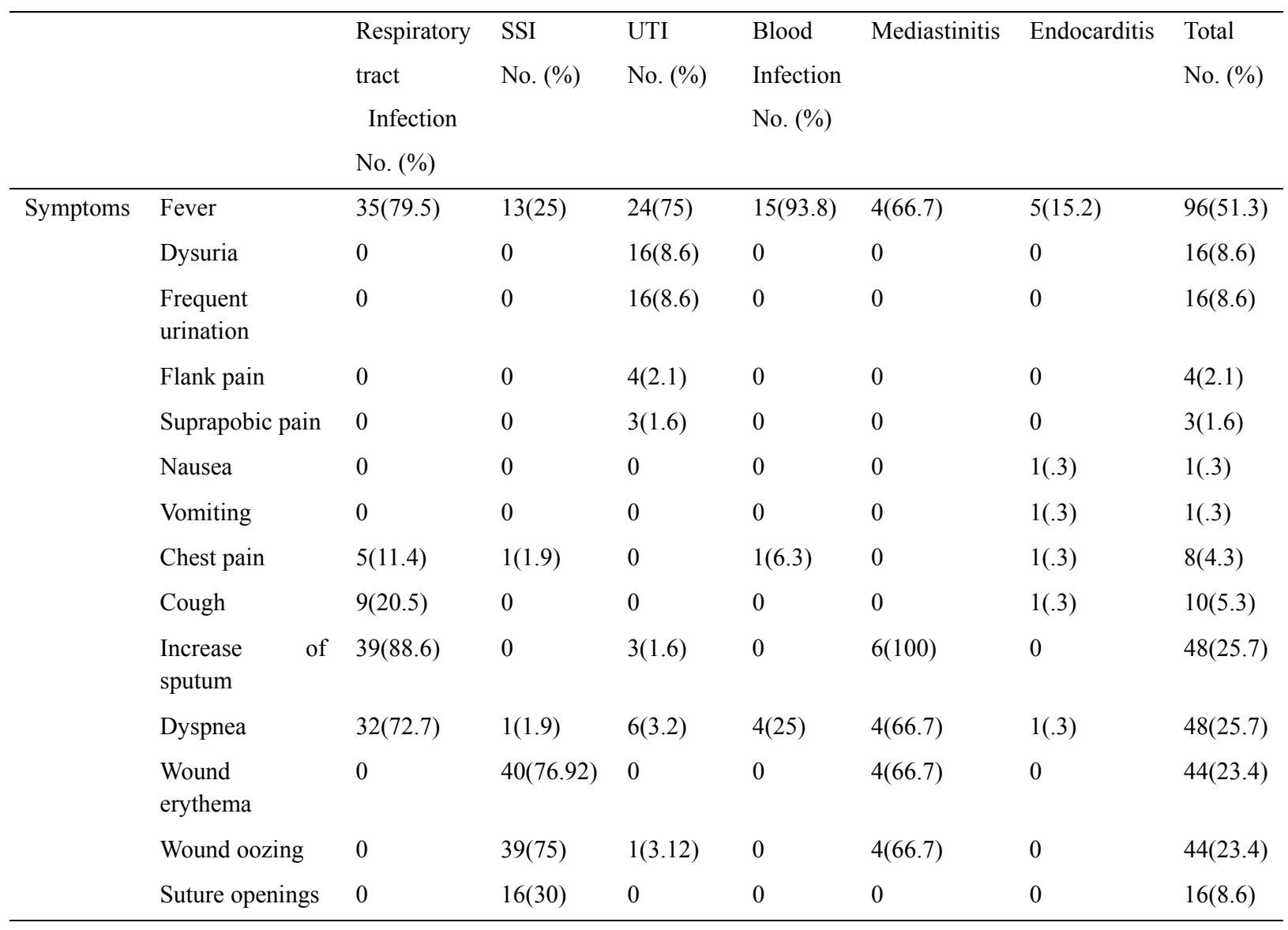

Table 3. Causative agent of NIs

\begin{tabular}{llllllll}
\hline $\begin{array}{l}\text { Causative agent } \\
\text { by site }\end{array}$ & \multicolumn{7}{c}{ No.(\%) episodes of infection } \\
\hline \multirow{3}{*}{ NO } & SSI & $\begin{array}{l}\text { Respiratory } \\
\text { Infection }\end{array}$ & UTI & B lood & Mediastinitis & Endocarditis & Total \\
& NO (\%) & Infection & NO (\%) & NO (\%) & (N=187) \\
& $52(27.8)$ & NO (\%) & $32(17.1)$ & NO (\%) & $6(3.2)$ & $33(17.6)$ & NO (\%) \\
& $48(25.6)$ & & $16(8.55)$ & & & \\
\hline P. aeruginosa & $2(3.84)$ & $8(16.66)$ & $2(6.25)$ & 0 & 0 & 0 & $12(13.79 \%)$ \\
Acinetobacter.spp & $1(1.92)$ & $3(6.25)$ & $1(3.12)$ & 0 & $1(16.6)$ & $1(3.03)$ & $7(8.04 \%)$ \\
E.coli & $7(13.46)$ & $6(12.5)$ & $16(50)$ & 0 & 0 & 0 & $29(33.33 \%)$ \\
Enterobacter. spp & $3(5.76)$ & $2(4.16)$ & $3(9.37)$ & 0 & 0 & 0 & $8(9.19 \%)$ \\
Klebsiella.spp & $3(5.76)$ & 0 & $3(9.37)$ & $1(6.25)$ & 0 & 0 & $7(8.04 \%)$ \\
S. aureus & $14(26.92)$ & $5(10.41)$ & 0 & $6(37.5)$ & $3(18.75)$ & $5(9.09)$ & $33(37.93 \%)$ \\
S. epidermidis & $1(1.92)$ & 0 & $1(3.12)$ & 0 & 0 & 0 & $2(2.29 \%)$ \\
Enterococci & 0 & 0 & 0 & 0 & 0 & $1(3.03)$ & $1(1.14 \%)$ \\
Culture negative & $21(4.3)$ & $20(41.66)$ & $6(18.75)$ & $9(56.25)$ & $2(33.33)$ & $26(78.78)$ & $88(47.1 \%)$ \\
\hline
\end{tabular}


Table 4. Antibiotic resistance pattern of gram negative bacteria isolated from infection

\begin{tabular}{|c|c|c|c|c|c|c|c|c|c|c|c|c|c|c|c|}
\hline \multirow[b]{2}{*}{ Antibiotics } & \multicolumn{3}{|c|}{$\begin{array}{l}\text { P.aeuroginosa } \\
\text { NO.(\%) }\end{array}$} & \multicolumn{3}{|c|}{$\begin{array}{l}\text { Acinetobacter.spp } \\
\text { NO.(\%) }\end{array}$} & \multicolumn{3}{|l|}{$\begin{array}{l}\text { E.coli } \\
\text { NO.(\%) }\end{array}$} & \multicolumn{3}{|c|}{$\begin{array}{l}\text { Enterobacter .spp } \\
\text { NO.(\%) }\end{array}$} & \multicolumn{3}{|c|}{$\begin{array}{l}\text { Klebsiella.spp } \\
\text { NO.(\%) }\end{array}$} \\
\hline & $\mathrm{S}$ & I & $\mathrm{R}$ & $\mathrm{S}$ & I & $\mathrm{R}$ & $\mathrm{S}$ & I & $\mathrm{R}$ & $\mathrm{S}$ & I & $\mathrm{R}$ & $\mathrm{S}$ & I & $\mathrm{R}$ \\
\hline Cef & 0 & $\begin{array}{l}10 \\
(83.3)\end{array}$ & $\begin{array}{l}2 \\
(16.6)\end{array}$ & 0 & 0 & $(100)$ & $\begin{array}{l}3 \\
(10.3)\end{array}$ & $\begin{array}{l}24 \\
(82.75)\end{array}$ & $\begin{array}{l}2 \\
(6.89)\end{array}$ & $\begin{array}{l}4 \\
(50)\end{array}$ & $\begin{array}{l}3 \\
(37.5)\end{array}$ & $\begin{array}{l}1 \\
(12.5)\end{array}$ & 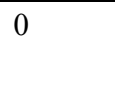 & $\begin{array}{l}3 \\
(37.5)\end{array}$ & $\begin{array}{l}4 \\
(57.1)\end{array}$ \\
\hline Cefta & $\begin{array}{l}2 \\
(16.6)\end{array}$ & $\begin{array}{l}4 \\
(33.3)\end{array}$ & $\begin{array}{l}6 \\
(50)\end{array}$ & 0 & 0 & $\begin{array}{l}7 \\
(100)\end{array}$ & $\begin{array}{l}3 \\
(10.3)\end{array}$ & $\begin{array}{l}18 \\
(62.06)\end{array}$ & $\begin{array}{l}8 \\
(27.5)\end{array}$ & 0 & $\begin{array}{l}3 \\
(37.5)\end{array}$ & $\begin{array}{l}5 \\
(62.5)\end{array}$ & $\begin{array}{l}1 \\
(14.2)\end{array}$ & $\begin{array}{l}1 \\
(14.2)\end{array}$ & $\begin{array}{l}5 \\
(71.42)\end{array}$ \\
\hline Ciprofloxacin & $\begin{array}{l}2 \\
(16.6)\end{array}$ & $\begin{array}{l}8 \\
(66.6)\end{array}$ & $\begin{array}{l}2 \\
(16.6)\end{array}$ & 0 & 0 & $\begin{array}{l}7 \\
(100)\end{array}$ & $\begin{array}{l}3 \\
(10.3)\end{array}$ & $\begin{array}{l}24 \\
(82.7)\end{array}$ & $\begin{array}{l}2 \\
(6.89)\end{array}$ & $\begin{array}{l}3 \\
(37.5)\end{array}$ & $\begin{array}{l}3 \\
(37.5)\end{array}$ & $\begin{array}{l}2 \\
(25)\end{array}$ & $\begin{array}{l}1 \\
(14.2)\end{array}$ & $\begin{array}{l}2 \\
(28.5)\end{array}$ & $\begin{array}{l}4 \\
(57.1)\end{array}$ \\
\hline Genta & $\begin{array}{l}10 \\
(83.3)\end{array}$ & 0 & $\begin{array}{l}2 \\
(16.6)\end{array}$ & 0 & 0 & $\begin{array}{l}7 \\
(100)\end{array}$ & $\begin{array}{l}25 \\
(86.2)\end{array}$ & $\begin{array}{l}2 \\
(6.89)\end{array}$ & $\begin{array}{l}2 \\
(6.89)\end{array}$ & $\begin{array}{l}3 \\
(37.5)\end{array}$ & $\begin{array}{l}2 \\
(25)\end{array}$ & $\begin{array}{l}3 \\
(37.5)\end{array}$ & $\begin{array}{l}3 \\
(37.5)\end{array}$ & $\begin{array}{l}1 \\
(14.2)\end{array}$ & $\begin{array}{l}3 \\
(42.85)\end{array}$ \\
\hline Amika & $\begin{array}{l}10 \\
(83.3)\end{array}$ & $\begin{array}{l}2 \\
(16.6)\end{array}$ & 0 & 0 & 0 & $\begin{array}{l}7 \\
(100)\end{array}$ & $\begin{array}{l}27 \\
(93.1)\end{array}$ & 0 & $\begin{array}{l}2 \\
(6.89)\end{array}$ & $\begin{array}{l}3 \\
(37.5)\end{array}$ & $\begin{array}{l}2 \\
(25)\end{array}$ & $\begin{array}{l}3 \\
(37.5)\end{array}$ & $\begin{array}{l}4 \\
(57.1)\end{array}$ & 0 & $\begin{array}{l}3 \\
(42.85)\end{array}$ \\
\hline Imipenem & $\begin{array}{l}10 \\
(83.3)\end{array}$ & 0 & $\begin{array}{l}2 \\
(16.6)\end{array}$ & 0 & 0 & $\begin{array}{l}7 \\
(100)\end{array}$ & $\begin{array}{l}23 \\
(79.3)\end{array}$ & $\begin{array}{l}2 \\
(6.89)\end{array}$ & $\begin{array}{l}4 \\
(13.8)\end{array}$ & $\begin{array}{l}2 \\
(25)\end{array}$ & $\begin{array}{l}1 \\
(12.5)\end{array}$ & $\begin{array}{l}5 \\
(62.5)\end{array}$ & $\begin{array}{l}3 \\
(37.5)\end{array}$ & $\begin{array}{l}1 \\
(14.2)\end{array}$ & $\begin{array}{l}3 \\
(42.85)\end{array}$ \\
\hline Novobiocin & 0 & $\begin{array}{l}10 \\
(83.3)\end{array}$ & $\begin{array}{l}2 \\
(16.6)\end{array}$ & 0 & 0 & $\begin{array}{l}7 \\
(100)\end{array}$ & $\begin{array}{l}8 \\
(27.58)\end{array}$ & $\begin{array}{l}19 \\
(65.51)\end{array}$ & $\begin{array}{l}2 \\
(6.89)\end{array}$ & $\begin{array}{l}1 \\
(12.5)\end{array}$ & $\begin{array}{l}2 \\
(25)\end{array}$ & $\begin{array}{l}5 \\
(62.5)\end{array}$ & $\begin{array}{l}3 \\
(42.85)\end{array}$ & $\begin{array}{l}2 \\
(28.5)\end{array}$ & $\begin{array}{l}2 \\
(28.5)\end{array}$ \\
\hline
\end{tabular}

Table 5. Antibiotic resistance of gram positive bacteria isolated from infection

\begin{tabular}{lllllll}
\hline & \multicolumn{1}{l}{$\begin{array}{l}\text { S.aureus NO } \\
(\%)\end{array}$} & & \multicolumn{5}{c}{$\begin{array}{c}\text { Sepidermidis NO } \\
(\%)\end{array}$} \\
\cline { 2 - 7 } & $\mathrm{S}$ & $\mathrm{I}$ & $\mathrm{R}$ & $\mathrm{S}$ & $\mathrm{I}$ & $\mathrm{R}$ \\
\hline Ampicillin & $4(12.9)$ & $15(48.38)$ & $12(38.70)$ & 0 & $2(100)$ & 0 \\
Penicillin & 0 & $19(61.29)$ & $12(38.70)$ & 0 & $2(100)$ & 0 \\
Oxacillin & $2(6.45)$ & $3(9.67)$ & $26(83.87)$ & 0 & 0 & $2(100)$ \\
Vancomycin & $30(96.77)$ & 0 & $1(3.22)$ & $2(100)$ & 0 & 0 \\
Clindamycin & 0 & $19(61.29)$ & $12(38.70)$ & $2(100)$ & 0 & 0 \\
Co-trimoxazole & 0 & $19(61.29)$ & $12(38.70)$ & 0 & 0 & $2(100)$ \\
Norfloxacin & $7(22.58)$ & $12(38.70)$ & $19(61.29)$ & $2(100)$ & 0 & 0 \\
Cefalotin & 17 & $7(22.58)$ & $7(22.58)$ & 0 & $2(100)$ & 0 \\
\hline
\end{tabular}

\section{Discussions}

Despite advances in antisepsis, asepsis, antibiotic prophylaxis and in surgical techniques, NIs continue to complicate after surgery in many patients (Segers et al., 2006). The rate of NIs in our study was $8.3 \%$. Lomtadze et al. and Levy et al. reported the incidence of NIs in about $16 \%$ of patients that underwent heart surgery (Segers et al., 2006; Lee et al., 2010). However the rate of NIs in Sarvikivi et al study was $25 \%$ (Sarvikivi et al., 2007). The rate of NIs after heart surgery in the study of Kollef, Sharpless et al. conducted in 1997 was $5-21 \%$ (Kollef et al., 1997). Michalopoulos and colleagues reported that 5\% of patients developed microbiologically documented NIs after open cardiac surgery which is close to our findings (Michalopoulos et al., 2006).

SSI accounts for $15 \%$ of all NIs among surgical patients (Lee et al., 2010). SSI was diagnosed in $3 \%$ of the patients in Lepelletier et al study but in $13.5 \%$ in Lee et al study that was performed in Taiwan (Lee et al., 2010; Lepelletier et al., 2005). The most causative agent of SSI was S.aureus in our study. Similarly, this agent was the most common organism isolated in Mundhada et al. research (Mundhada \& Tenpe, 2015). Lemaignen et al. 
reported $4.1 \%$ occurrence of SSIs after cardiac surgery and, S.aureus was the most prevalent microorganism associated with them (Lemaignen et al., 2015). Risk factors for SSI were older age and diabetes in our study. Diabetes is one of the risk factors for the development of postoperative Nis in surgical patients. Patients with diabetes are more susceptible to many types of infection, including NIs and this has been the findings of Yamashita et al and Vardakas et al. (Yamashita et al., 2000; Vardakas et al., 2007). We observed that 4.3\% of SSI was negative culture. The appearance of postoperative SSI in the absence of cultivable bacterial pathogens is a usual dilemma for the surgeons. Culture-negative SSIs happen because of prior antimicrobial therapies, the presence of fastidious or slow-growing bacteria such as Legionella spp, mycobacteria and Mycoplasma spp and infections caused by mundane bacteria that may be dismissed as contaminants, etc. (Rasnake \& Dooley, 2006; Reddy, 2012).

Riera et al in Spain showed the rate of nosocomial pneumonia was $1.2 \%$ and the main risk factors for respiratory tract infections were left ventricular ejection fraction (Riera et al., 2010). Lomtadze et al in Georgia reported that the rate of nosocomial respiratory tract infections was $7 \%$ after heart surgery. Consistent with our results, Mechanical ventilation was one of the most common risk factors in Lomtadze et al study (Lomtadze et al., 2010; Lemaignen et al., 2015). P. aeruginosa and S. aureus were the most found bacteria isolated in pneumonia. In NIs pneumonia, P. aeruginosa, A. baumannii, and the Enterobacteriaceae are the main bacteria (Anton et al., 2010). We showed that $41.66 \%$ of pneumonia patients had negative culture results. Negative upper airway swab, alternative sampling methods such as induced sputum or broncho alveolar lavage may cause negative culture in NIs pneumonia (Ahmed et al., 2014).

Nosocomial endocarditis is associated with total parenteral nutrition lines, presence of intravenous catheters, pacemakers, etc. (Kasper \& Harrison, 2005). In our study, 24.4\% of the patients with nosocomial endocarditis had mechanical intubation and most causative bacteria were S. aureus. Enterococci and Streptococcus bovis were the most frequent bacteria in Barrau et al study (Barrau et al., 2004). Close to our findings, Takayama found $S$. aureus was responsible for endocarditis in $21.3 \%$ of the cases (Takayama et al., 2010). Close to $80 \%$ of endocarditis were negative culture, because some germs do not grow well in a laboratory setting and some people have taken antibiotics in the past that keep germs from growing.

The rate of UTI was $17.1 \%$ in our study and the main risk factor was urine catheter that was used on our patients. In a study that was conducted by Sodano et al in Italy, the rates of catheter-associated and device-associated UTIs in heart surgery patients were 5.8\% and.6\% respectively (Sodano et al., 2004). Also Mirinazhad et al. in Iran showed that all the patients had NIs associated with positive urine culture related to catheter-associated UTI. The most common microorganisms that Mirinazhad et al isolated were Enterobacter spp. (37.5\%) (Mirinazhad et al., 2011). However E.coli was the most common bacteria isolated in our study. According to many studies in Iran, the main cause of UTI is still E. coli (Aminizadeh \& Kashi, 2011; Behzadnia et al., 2014; Rezai et al., 2015; Saffar et al., 2008; Davoudi et al., 2012). In our study, $18.7 \%$ of the patients with UTI had negative culture.

Lomtadze et al. found the rate of blood infection to be $7.75 \%$ which is consistent with our results (Lomtadze et al., 2010). Barker reported $0.3 \%$ mediastinitis and $0.09 \%$ endocarditis in pediatric patients after cardiac surgery (Barker et al., 2010). Al-Hazmi showed E. coli, Enterococcus and Pseudomonas are the most common organisms isolated from blood infections (Al-Hazmi et al., 2014). In our study, the most prevalent bacteria isolated from mediastinitis was S.aureus as it was in the study of Ghotaslou et al which is similar to our findings (Ghotaslou et al., 2008).

In our study, among Gram-negative enterobacteriaceae, E.coli and P. Aeruginosa, and among Gram-positive bacteria $S$. aureus was the most common isolated bacteria. Lavakhamseh et al. showed that the most common bacterium isolated from patients with NIs was $E$. coli with $68.51 \%$ rate, and the highest resistance was found for Co-trimoxazole with 57.47\% incidence (Lavakhamseh et al., 2014). In our study E.coli and Enterobacter .spp have shown high levels of resistance to Ceftazidime, Imipenem, Gentamicin and Amikacin respectively. Resistance to antibiotics among P. aeuroginosa was $16.6 \%$ to Ceftriaxone, Ceftazidime, Ciprofloxacin, Gentamicin, Amikacin, and Imipenem. Incidence of resistance to Ceftazidime, ceftriaxone and Ciprofloxacin among Klebsiella.spp was $71.42 \%, 57.1 \%$ and $57.1 \%$ respectively. Results in our study showed all Acinetobacter.spp were MDR. The rate of ESBL-producing bacteria was $14.28-71.42 \%$ in our study. ESBL-producing bacteria confer significant resistance to penicillin, aztreonam antibiotics and narrow and extended-spectrum cephalosporin. They also frequently show resistance to aminoglycosides, trimethoprim/sulfamethoxazole and quinolones (Paterson et al., 2003). In consistent with our result, Rezai et al. reported 30.5\% ESBL-producing E.coli (Rezai et al., 2015). Also the rates of extended-spectrum beta-lactamase production in K. pneumoniae and E. coli strains were determined as $14 \%$ and $6 \%$ respectively in Surucuoglu et al. study (Surucuoglu et al., 2005). ESBL-producing isolates have been responsible for provoking outbreaks in 
many hospitals. Considering that these genes are located in plasmid they can spread in hospital environment.

S. aurous and S.epidermidis had high rates of antibiotic resistance. However resistance to vancomycin was observed in one isolated $S$. aurous. In our study, the rate of MRSA $S$. aurous was $54.2 \%$. Azimian et al reported the incidence of MRSA S. aurous to be $47.5 \%$ (Azimian et al., 2012). Although Abdulgader showed that the proportion of Panton-Valentine leukocidin positive MRSA carriage infections ranged from 0.3 to $100 \%$ in humans (Abdulgader et al., 2015). MRSA is responsible for an increasing number of serious hospital and community-acquired infections. NIs with MRSA strains requires treatment with glycopeptide antibiotics which are nephrotoxic (Nelson et al., 2015; Pacheco et al., 2011).

Studies examining NIs bacteremia have shown that infection due to antibiotic-resistant pathogens is usually associated with greater patient mortality compared to the same infections attributed to antibiotic-sensitive bacteria (Chow et al., 1991; Rezai et al., 2012). It is necessary that infection control procedures be implemented carefully and antibiotic resistance patterns of organisms causing NIs should be checked periodically, specifically in heart surgery centers to guide empirical antibiotic therapies

\section{Conclusions}

Our study shows that although the rate of NIs following open heart surgery is within a reasonable limit, but MDR gram-negative bacteria and gram-positive bacteria are increasing. This issue can seriously affect the outcome of patients who underwent heart surgery. Therefore, using effective measures such as infection control, isolation of patients with MDR infections and implementation of antibiotic stewardship is recommended.

\section{Acknowledgments}

The authors of this article have the utmost gratitude to the Vice-Chancellor for Research at Mazandaran University of Medical Sciences for providing financial support for this research project. This article is result of Dr. Amirhosein Heydari thesis with 9135 grant number.

\section{Conflict of Interest}

None declared.

\section{References}

Abdulgader, S. M., Shittu, A. O., Nicol, M. P., \& Kaba, M. (2015). Molecular epidemiology of Methicillin-resistant Staphylococcus aureus in Africa: A systematic review. Front Microbiol, 6, 348. http://dx.doi.org/10.3389/fmicb.2015.00348

Ahmed, B., Bush, A., \& Davies, J. C. (2014). How to use: Bacterial cultures in diagnosing lower respiratory tract infections in cystic fibrosis. Arch Dis Child Educ Pract Ed, 99, 181-7. http://dx.doi.org/10.1136/archdis child-2012-303408

Al-Hazmi, H. H., Al-Zahrani, T., \& Elmalky, A. M. (2014). Hospital acquired blood stream infection as an adverse outcome for patients admitted to hospital with other principle diagnosis. Saudi J Anaesth, 8, S84-8. http://dx.doi.org/10.4103/1658-354X.144084

Aminizadeh, Z., \& Kashi, M. (2011). Prevalence of multi-drug resistance and pandrug resistance among multiple gram-negative species: Experience in one teaching hospital, Tehran, Iran. Int Res J Microbiol, 2, 90-95.

Anton, Y., Peleg, M., \& Hooper, D. (2010). Hospital-Acquired Infections Due to Gram-Negative Bacteria. $N$ Engl J Med, 362, 1804-1813. http://dx.doi.org/10.1056/NEJMra0904124

Azimian, A., Najar-Pirayeh, S., Mirab-Samiee, S., \& Naderi, M. (2012). Occurrence of methicillin resistant Staphylococcus aureus (MRSA) among clinical samples in tehran-iran and its correlation with polymorphism of specific accessory gene regulator (AGR) groups. Braz J Microbiol, 43, 779-85. http://dx.doi.org/10.1590/S1517-83822012000200043

Barker, G. M., O'brien, S. M., Welke, K. F., Jacobs, M. L., Jacobs, J. P., Benjamin, D. K., Jr., ... Li, J. S. (2010). Major infection after pediatric cardiac surgery: A risk estimation model. Ann Thorac Surg, 89, 843-50. http://dx.doi.org/10.1016/j.athoracsur.2009.11.048

Barrau, K., Boulamery, A., Imbert, G., Casalta, J. P., Habib, G., Messana, T., ... Raoult, D. (2004). Causative organisms of infective endocarditis according to host status. Clin Microbiol Infect, 10, 302-8. http://dx.doi.org/10.1111/j.1198-743X.2004.00776.x

Behzadnia, S., Davoudi, A., Rezai, M. S., \& Ahangarkani, F. (2014). Nosocomial infections in pediatric population and antibiotic resistance of the causative organisms in north of Iran. Iran Red Crescent Med J, 
16, e14562. http://dx.doi.org/10.5812/ircmj.14562

Chow, J. W., Fine, M. J., Shlaes, D. M., Quinn, J. P., Hooper, D. C., Johnson, M. P., ... Yu, V. L. (1991) Enterobacter bacteremia: Clinical features and emergence of antibiotic resistance during therapy. Ann Intern Med., 115(8), 585-90. http://dx.doi.org/10.7326/0003-4819-115-8-585

Collee, J., Miles, R., \& Watt, B. (1996). Tests for the identification of bacteria. Mackie and McCartney. Practical Medical Microbiolog (14th ed.). London: Churchill Livingstone.

Davoudi, A. R., Najafi, N., Hoseini Shirazi, M., \& Ahangarkani, F. (2012). Frequency of bacterial agents isolated from patients with nosocomial infection in teaching hospitals of Mazandaran University of Medical Sciences in 2012. Caspian J Intern Med, 5, 227-31.

Ding, J. G., Sun, Q. F., Li, K. C., Zheng, M. H., Miao, X. H., Ni, W., ... He, W. F. (2009). Retrospective analysis of nosocomial infections in the intensive care unit of a tertiary hospital in China during 2003 and 2007. BMC Infect Dis, 9, 115. http://dx.doi.org/10.1186/1471-2334-9-115

Ghotaslou, R., Yagoubi, A. R., Khalili, A. A., \& Mahmodian, R. (2008). Mediastinitis after cardiac surgery in Madani Heart Center, Tabriz, Iran. Jpn J Infect Dis, 61, 318-20.

Goldmann, D. A., Weinstein, R. A., Wenzel, R. P., Tablan, O. C., Duma, R. J., Gaynes, R. P., ... Martone, W. J. (1996). Strategies to Prevent and Control the Emergence and Spread of Antimicrobial-Resistant Microorganisms in Hospitals. A challenge to hospital leadership. JAMA, 275, 234-40. http://dx.doi.org/ 10.1001/jama.1996.03530270074035

Jarlier, V., Nicolas, M., Fournier, G., \& Philippon, A. (1988). Extended broad-spectrum beta-lactamases conferring transferable resistance to newer beta-lactam agents in Enterobacteriaceae: Hospital prevalence and susceptibility patterns. Rev Infect Dis, 10, 867-878. http://dx.doi.org/10.1093/clinids/10.4.867

Kasper, D. L., \& Harrison, T. R. (2005). Harrison's principles of internal medicine. New York, McGraw-Hill, Medical Pub. Division.

Kollef, M. H., Sharpless, L., Vlasnik, J., Pasque, C., Murphy, D., \& Fraser, V. J. (1997). The impact of nosocomial infections on patient outcomes following cardiac surgery. Chest, 112, 666-75. http://dx.doi.org /10.1378/chest.112.3.666

Kollef, M. H., Wragge, T., \& Pasque, C. (1995). Determinants of mortality and multiorgan dysfunction in cardiac surgery patients requiring prolonged mechanical ventilation. Chest, 107, 1395-401. http://dx.doi.org /10.1378/chest.107.5.1395

Koneman, E., Allen, S., Janda, W., Schreckenberger, R., \& Winn, W. (1997). Introduction to microbiology. Part II: Guidelines for the collection transport, processing analysis and reporting of culture from specific specimen sources. Philadelphia: Lippincott-Raven. 6.

Lavakhamseh, H., Shakib, P., Rouhi, S., Mohammadi, B., \& Ramazanzadeh, R. (2014). A survey on the prevalence and antibiotic sensitivity of nosocomial infections in the besat hospital, SANANDAJ, IRAN. Journal NI, 1, 1-8.

Lee, Y. P., Feng, M. C., Wu, L. C., Chen, S. H., Chen, Y. H., Chiu, C. C., .. Lu, P. L. (2010). Outcome and risk factors associated with surgical site infections after cardiac surgery in a Taiwan medical center. $J$ Microbiol Immunol Infect, 43, 378-85. http://dx.doi.org/10.1016/S1684-1182(10)60060-6

Lemaignen, A., Birgand, G., Ghodhbane, W., Alkhoder, S., Lolom, I., Belorgey, S., ... Lucet, J. C. (2015). Sternal wound infection after cardiac surgery: Incidence and risk factors according to clinical presentation. Clin Microbiol Infect. http://dx.doi.org/10.1016/j.cmi.2015.03.025

Lepelletier, D., Perron, S., Bizouarn, P., Caillon, J., Drugeon, H., Michaud, J. L., \& Duveau, D. (2005). Surgical-site infection after cardiac surgery: Incidence, microbiology, and risk factors. Infect Control Hosp Epidemiol, 26, 466-72. http://dx.doi.org/10.1086/502569

Lola, I., Levidiotou, S., Petrou, A., Arnaoutoglou, H., Apostolakis, E. \& Papadopoulos, G. S. (2011). Are there independent predisposing factors for postoperative infections following open heart surgery? J Cardiothorac Surg, 6, 151. http://dx.doi.org/10.1186/1749-8090-6-151

Lomtadze, M., Chkhaidze, M., Mgeladze, E., Metreveli, I., \& Tsintsadze, A. (2010). Incidence and risk factors of nosocomial infections after cardiac surgery in Georgian population with congenital heart diseases. Georgian Med News, 7-11. 
Masoumi, A. (2007). Directory of nosocomial infections surveillance system (2th ed.). Tehran: The center of management of contagious diseases. Ministry of Health and Medical Education of Islamic Republic of Iran.

Michalopoulos, A., Geroulanos, S., Rosmarakis, E. S., \& Falagas, M. E. (2006). Frequency, characteristics, and predictors of microbiologically documented nosocomial infections after cardiac surgery. Eur $J$ Cardiothorac Surg, 29, 456-60. http://dx.doi.org/10.1016/j.ejcts.2005.12.035

Mirinazhad, M., Chavoshinazhad, M., \& Ghorbanian, N. (2011). Epidemiologic and Etiologic Evaluation of Acquired Urinary Tract Infections in Cardiac Surgery ICU Patients. J Cardiovasc Thorac Res, 3, 29-33.

Mundhada, A. S., \& Tenpe, S. (2015). A study of organisms causing surgical site infections and their antimicrobial susceptibility in a tertiary care Government Hospital. Indian J Pathol Microbiol, 58, 195-200. http://dx.doi.org/10.4103/0377-4929.155313

Nelson, M. U., Bizzarro, M. J., Baltimore, R. S., Dembry, L. M., \& Gallagher, P. G. (2015). Clinical and Molecular Epidemiology of Methicillin-Resistant Staphylococcus aureus in a Neonatal Intensive Care Unit in the Decade Following Implementation of an Active Detection and Isolation Program. J Clin Microbiol. http://dx.doi.org/10.1128/JCM.00470-15

Pacheco, R. L., Lobo, R. D., Oliveira, M. S., Farina, E. F., Santos, C. R., Costa, S. F., ... Levin, A. S. (2011). Methicillin-resistant Staphylococcus aureus (MRSA) carriage in a dermatology unit. Clinics (Sao Paulo). 66(12), 2071-7. http://dx.doi.org/10.1590/S1807-59322011001200012

Paterson, D. L., Hujer, K. M., Hujer, A. M., Yeiser, B., Bonomo, M. D., Rice, L. B., \& Bonomo, R. A. (2003). Extended-spectrum beta-lactamases in Klebsiella pneumoniae bloodstream isolates from seven countries: Dominance and widespread prevalence of SHV- and CTX-M-type beta-lactamases. Antimicrob Agents Chemother, 47, 3554-60. http://dx.doi.org/10.1128/AAC.47.11.3554-3560.2003

Rahmati, M., Razaghi, A., Doostdar, H., Yaghoubi, H., Masoumi, S., \& Rezai, M.-S. (2014). Comparison of azithromycin, amoxicillin and amoxicillin/clavulanicacid in the treatment of children with acute bacterial sinusitis. Journal of Mazandaran University of Medical Sciences, 23, 183-190.

Ramazanzadeh, R. (2010) Etiologic agents and extended-spectrum beta-lactamase production in urinary tract infections in Sanandaj, Iran. Eastern Journal of Medicine, 15, 57-62.

Rasnake, M. S., \& Dooley, D. P. (2006). Culture-negative surgical site infections. Surg Infect (Larchmt), 7 , 555-65. http://dx.doi.org/10.1089/sur.2006.7.555

Reddy, B. (2012). Culture negative surgical site infections. J Med Allied Sci, 2, 2-6.

Rezai, M., Ghaffari, V., Abbaskhanian, A., \& Puramiri, R. (2012). Comparison of once versus twice daily dose of amikacin in neonatal early sepsis. HealthMed, 6, 3946-3951.

Rezai, M. S., Salehifar, E., Rafiei, A., Langaee, T., Rafati, M., Shafahi, K., \& Eslami, G. (2015). Characterization of Multidrug Resistant Extended-Spectrum Beta-Lactamase-Producing Escherichia coli among Uropathogens of Pediatrics in North of Iran. BioMed Research International, 7. http://dx.doi.org/10. $1155 / 2015 / 309478$

Riera, M., Ibanez, J., Herrero, J., Ignacio Saez De Ibarra, J., Enriquez, F., Campillo, C., \& Bonnin, O. (2010) Respiratory tract infections after cardiac surgery: impact on hospital morbidity and mortality. J Cardiovasc Surg (Torino), 51, 907-14.

Saffar, M., Enayti, A., Abdolla, I., Razai, M., \& Saffar, H. (2008). Antibacterial susceptibility of uropathogens in 3 hospitals, Sari, Islamic Republic of Iran, 2002-2003. Eastern Mediterranean Health Journal, 14, 556-563.

Sarvikivi, E., Lyytikainen, O., Nieminen, H., Sairanen, H., \& Saxen, H. (2007). Nosocomial infections after pediatric cardiac surgery. Am J Infect Control, 36(8), 564-9. http://dx.doi.org/10.1016/j.ajic.2007.11.006

Segers, P., Speekenbrink, R. G., Ubbink, D. T., Van Ogtrop, M. L., \& De Mol, B. A. (2006). Prevention of nosocomial infection in cardiac surgery by decontamination of the nasopharynx and oropharynx with chlorhexidine gluconate: A randomized controlled trial. JAMA, 296, 2460-6. http://dx.doi.org/10.1001/jama. 296.20.2460

Sodano, L., Agodi, A., Barchitta, M., Musumeci, F., Menichetti, A., Bellocchi, P., ... Coco, G. (2004). Nosocomial infections in heart surgery patients: Active surveillance in two Italian hospitals. Ann Ig, 16, 735-43.

Surucuoglu, S., Gazi, H., Kurutepe, S., Ozkutuk, N., \& Ozbakkaloglu, B. (2005). Bacteriology of surgical wound 
infections in a tertiary care hospital in Turkey. East Afr Med J, 82, 331-6.

Takayama, Y., Okamoto, R., \& Sunakawa, K. (2010). Definite infective endocarditis: Clinical and microbiological features of 155 episodes in one Japanese university hospital. J Formos Med Assoc, 109, 788-99. http://dx.doi.org/10.1016/S0929-6646(10)60124-6

Vardakas, K. Z., Siempos, Ii, \& Falagas, M. E. (2007) Diabetes mellitus as a risk factor for nosocomial pneumonia and associated mortality. Diabet Med, 24, 1168-71. http://dx.doi.org/10.1111/j.1464-5491. 2007.02234.x

Yamashita, S., Yamaguchi, H., Sakaguchi, M., Satsumae, T., Yamamoto, S., \& Shinya, F. (2000). Longer-term diabetic patients have a more frequent incidence of nosocomial infections after elective gastrectomy. Anesth Analg, 91, 1176-81.

\section{Copyrights}

Copyright for this article is retained by the author(s), with first publication rights granted to the journal.

This is an open-access article distributed under the terms and conditions of the Creative Commons Attribution license (http://creativecommons.org/licenses/by/3.0/). 